\title{
The fatty acid profiles in $M$. longissimus dorsi and M. semimembranosus of short-haired and long-haired crossbred sheep meat
}

\author{
Pattraphorn Patthararangsarith ${ }^{1}$ and Kunya Tuntivisoottikul ${ }^{1, *}$ \\ ${ }^{1}$ Agricultural Education Department, Faculty of Industrial Education and Technology, King Mongkut's Institute of Technology \\ Ladkrabang, Bangkok, Thailand
}

\begin{abstract}
This study was conducted to investigate the effects of crossbred groups and anatomical muscle positions on the chemical composition and fatty acid profiles in the loin (M. longissimus dorsi) and chump (M. semimembranosus) muscles of the short-haired and long-haired crossbred sheep. Five sheep per group with the $25 \mathrm{~kg}$ initial body weight were fed with $2 \mathrm{~kg} / \mathrm{d}$ TMR and free choice grass (Brachiaria mutica), and those were raised 84 days. After slaughter, loin and chump were used to examine the chemical composition and fatty acid profiles. The results showed that the loin from the short-haired and long-haired crossbreds had Palmitic acid at the highest level among the other saturated fatty acid (SFA), whereas this fatty acid was not detected in the chump. However, the highest SFA in the chump of both crossbreds was the Stearic acid. Furthermore, the fatty acids in both groups were detected in the chump more than in the loin. There was found that the nutritional values were not affected by sheep crossbred groups $(\mathrm{P}>0.05)$. The loin and chump had affected the percentage of crude protein $(\mathrm{P}<0.01)$, the amount of Lauric Acid $(\mathrm{C} 12: 0)$, and the total fatty acids $(\mathrm{P}<0.01)$. Interaction factor between the crossbred groups and the anatomical muscle positions was unaffected all the traits studied $(\mathrm{P}>0.05)$.
\end{abstract}

\section{Introduction}

Sheep (Ovis spp.) is the small ruminant which is widely propagated all over Thailand, especially in the southern part where has many Muslim populations. The characteristics of sheep production system in Thailand are the native breed, a small body size with $8-12 \mathrm{~kg}$ body weight, a small flock size, the low fertility traits, and the low technology used; therefore, the animal performance indices are below the biological potential, resulting in the low quality of final products. However, the advantages of these sheep are the disease resistance and the high potential for the environmental resource utilization. To enhance the productivity of the native sheep, crossbreeding with the foreign breeds is the common practice. Recently, Department of Livestock Development (DLD) Thailand imported the plenty of pure breeds for crossbreeding with the Thai native breed. Therefore, many crossbred lines were breed from Thai native and various foreign breeds such as Katahdin, Santa Inês, Dorper, Barbados Blackbelly, South African Mutton Merino, and Corriedale. Thus, these crossbreds are broadly contributed to the local farmers and the plenty sheep in Thailand were the undefined crossbred. Recently, the Santa Inês and Dorper breed that are recognized for their outstanding meat production were used as the terminal crossing between native breeds. Therefore, those exotic breeds widely emerged at the local farms [1]. In order to classify the undefined crossbred sheep, the appearance characteristics were described. In this experiment, the long-haired crossbred was expected that it has been dominated with the Dorper breed; in the other hand, the short-haired crossbred was illustrated the characteristics of the Santa Inês breed.

Adipose fat deposits have been emphasized in assessment studied of meat quality, as these deposits are increasingly being used in the improvement of texture and palatability of meat. The fatty acid profiles are the major contributor to meat quality in small ruminants. Moreover, they play the important role in coping with the health issue in the view of the high incidence of diseases. The pertinent attention was toward decreasing the percentage of saturated fatty acid (SFA) and increasing the percentage of unsaturated fatty acid (USFA); in addition, the poly-unsaturated fatty acid (PUFA) was desired. The fatty acid composition of meat might be influenced by a variety of factors, including animal breeding, feeding, and rearing system [2]. However, there is no documented result on the chemical composition and fatty acid profiles of the crossbred sheep in Thailand. Therefore, the objective of the present study was to investigate the effects of crossbreed groups and anatomical muscle positions on the chemical composition and the fatty acid profiles in the loin and chump of short-haired and long-haired crossbred sheep.

\footnotetext{
* Corresponding author: kunya.tu@kmitl.ac
} 


\section{Materials and Methods}

\subsection{Animals and production system}

The research was carried out at Suwanvajokkasikit Animal R\&D Institute, Kasetsart University, Kamphaeng Saen Campus, Nakorn Pathom Province, Thailand. The local altitude is $6 \mathrm{~m}$ above sea level at $13^{\circ} 59^{\prime} 2 \mathrm{~N}$ and $99^{\circ} 59^{\prime} 38^{\prime \prime} \mathrm{E}$. The temperature in the region varies between the minimum $18{ }^{\circ} \mathrm{C}$ to the maximum $40^{\circ} \mathrm{C}$, with an annual rainfall of 500-1,650 $\mathrm{mm}$. Ten male sheep, one-year-old with $25 \mathrm{~kg}$ initial body weight, equally represented the two crossbred groups; short-haired and long-haired crossbred sheep. Animals were raised in the confinement with the slatted floor. The animals were fed with $2 \mathrm{~kg} / \mathrm{d}$ TMR and free choice grass (Brachiaria mutica). The feed samples were analysed as the proximate analysis [3].

Table 1. Chemical composition of TMR and grass (Brachiaria mutica)

\begin{tabular}{|l|c|c|}
\hline \multirow{2}{*}{$\begin{array}{l}\text { Chemical } \\
\text { composition (\%) }\end{array}$} & \multicolumn{2}{|c|}{ Feed } \\
\cline { 2 - 3 } & TMR & Brachiaria mutica \\
\hline Dry matter & 88.83 & 21.97 \\
\hline Crude Protein & 13.65 & 6.20 \\
\hline Crude Fat & 4.70 & 0.15 \\
\hline Crude Fiber & 4.94 & 21.11 \\
\hline
\end{tabular}

\subsection{Chemical composition and fatty acid profiles}

At slaughter, sheep were weighted, stunned and killed by exsanquination. The gastrointestinal tract and skin were removed. The carcasses were split into two identical longitudinal halves. Tested muscle samples from M. longissimus dorsi and M. semimembranosus were taken for laboratory analysis component as the following: the percentages of moisture and dry matterby oven drying $105{ }^{\circ} \mathrm{C}$, crude protein- by the Kjeldahl method, crude fat- by Soxhlet extractor and crude ash by $550{ }^{\circ} \mathrm{C}$ heat [3] and fatty acid profiles- by gas chromatography [4].

\subsection{Statistical analysis}

Descriptive statistics were performed to calculate mean values and standard deviations for all variables. In addition, least squares procedures were used to analyse data for the chemical composition and the fatty acid profiles. The General Linear Model (GLM) were used in the analyses of these characteristics included the fixed effects of crossbred groups and the muscle anatomical positions. The option PDIFF was used for calculating significant differences between least squares means.

$$
\mathrm{Y}_{\mathrm{ijk}}=\mu+\mathrm{B}_{\mathrm{i}}+\mathrm{M}_{\mathrm{j}}+\mathrm{e}_{\mathrm{ijk}}
$$

where:

Y the dependent variable

$\mu \quad$ the overall mean
$B_{i} \quad$ fixed crossbred group effect, ( $\mathrm{i}=$ short-haired, long-haired crossbred)

$\mathrm{M}_{\mathrm{j}} \quad$ fixed anatomical muscle position effect ( $\mathrm{j}=$ M. longissimus dorsi, M. semimembranosus)

$\mathrm{e}_{\mathrm{ijk}}$ residual error

A pre-analysis showed that the interaction was not significant, so it was excluded out of the model.

\section{Results and discussions}

\subsection{The chemical composition in loin and chump of short-haired and long-haired crossbred sheep meat}

The chemical composition in loin and chump of shorthaired and long-haired crossbred sheep obtained in the experiment are described in Table 2. It was evidence that the percentage of moisture, crude protein, and crude fat of long-haired crossbred loin are greater than those short-haired crossbred loin $(75.83 \pm 1.19,23.37 \pm 1.77$, and $8.29 \pm 1.29$ vs $75.27 \pm 1.23,23.02 \pm 2.13$, and $8.11 \pm 1.10$, respectively). On the other hand, the percentage of dry matter and crude ash of short-haired crossbred loin are higher than those of long-haired crossbred loin $(24.73 \pm 1.23$ and $4.01 \pm 0.22$ vs $24.17 \pm 1.19$ and $3.68 \pm 0.36)$. It had been shown that the percentage of dry matter, crude fat and crude ash of long-haired crossbred chump are greater than those of short-haired crossbred chump. (24.31 $\pm 1.77,9.86 \pm 2.80$, and $4.17 \pm 0.36$ vs $24.09 \pm 0.94,8.20 \pm 1.66$, and $3.90 \pm 0.33$, respectively). Nonetheless, the percentage of moisture and crude protein of short-haired crossbred chump are higher than those of long-haired crossbred chump (75.91 \pm 0.94 , $19.91 \pm 1.09$ vs $75.69 \pm 1.77,19.80 \pm 0.84)$.

Table 2. Means ( \pm standard deviation), minimum and maximum values of the chemical composition in Loin and chump of the long-haired and short-haired crossbred sheep

\begin{tabular}{|l|c|c|c|c|c|c|}
\hline \multirow{2}{*}{$\begin{array}{l}\text { Chemical } \\
\text { composition }\end{array}$} & \multicolumn{2}{|c|}{ Long haired crossbred } & \multicolumn{3}{c|}{ Short haired crossbred } \\
\cline { 2 - 7 } & Mean \pm SD & Min & Max & Mean \pm SD & Min & Max \\
\hline Loin (M. longissimus dorsi) \\
\hline Moisture & $75.83 \pm 1.19$ & 73.89 & 76.91 & $75.27 \pm 1.23$ & 73.09 & 75.92 \\
\hline Dry matter & $24.17 \pm 1.19$ & 23.09 & 26.11 & $24.73 \pm 1.23$ & 24.08 & 26.91 \\
\hline $\begin{array}{l}\text { Crude } \\
\text { protein }\end{array}$ & $23.37 \pm 1.77$ & 20.65 & 25.04 & $23.02 \pm 2.13$ & 19.79 & 25.40 \\
\hline Crude fat & $8.29 \pm 1.29$ & 6.34 & 9.55 & $8.11 \pm 1.10$ & 6.84 & 9.54 \\
\hline Crude ash & $3.68 \pm 0.36$ & 3.30 & 4.08 & $4.01 \pm 0.22$ & 3.63 & 4.18 \\
\hline Chump (M. semimembranosus) & & & & \\
\hline Moisture & $75.69 \pm 1.77$ & 74.26 & 78.54 & $75.91 \pm 0.94$ & 74.89 & 77.13 \\
\hline Dry matter & $24.31 \pm 1.77$ & 21.46 & 25.74 & $24.09 \pm 0.94$ & 22.87 & 25.11 \\
\hline $\begin{array}{l}\text { Crude } \\
\text { protein }\end{array}$ & $19.80 \pm 0.84$ & 19.04 & 20.71 & $19.91 \pm 1.09$ & 18.72 & 21.11 \\
\hline Crude fat & $9.86 \pm 2.80$ & 7.10 & 13.85 & $8.20 \pm 1.66$ & 6.55 & 10.04 \\
\hline Crude ash & $4.17 \pm 0.36$ & 3.91 & 4.80 & $3.90 \pm 0.33$ & 3.55 & 4.30 \\
\hline
\end{tabular}

The data from Table 2 have been shown that the percentage of crude fat of both mention muscles (loin and chump) of long-haired crossbred sheep were higher than those of short-haired crossbred sheep. The longhaired crossbred sheep which was expected to be the crossbred between the native and Dorper breed has the greater average body weight than those of the shorthaired crossbred sheep which was anticipated to be the 
crossbred between the native and Santa Inês breed (the live body weight at slaughter $35.26 \pm 3.24$ and $34.00 \pm 2.22$ $\mathrm{kg}$, respectively). There was the substantial increase in the energy and fat contents of the weight when the body weight was increased from $15-30 \mathrm{~kg}$ [5]. It had been known that fat depot in the muscle as the intramuscular fat is play the important role for the meat quality. The intramuscular fat was significantly associated with the sensory of meat such as the tenderness, juiciness, and flavour. Therefore, the Dorper breed has been suggested to be the terminal line of crossing breed for improving the great potential for growth and the ability for accumulate intramuscular fat in muscle. However, many previous studies showed that the Santa Inês breed, a naturalized hair breed, is known for its low-fat meat production and good maternal traits providing an opportunity for crossbred with specialized meat breeds [6], [7]. This breed was suggested to be the terminal line for producing the crossbred as well.

\subsection{The fatty acid profiles in loin and chump of short-haired and long-haired crossbred sheep meat}

Table 3. Means and standard deviation values of the fatty acid profiles $(\mathrm{mg} / 100 \mathrm{~g})$ in the loin and chump muscle of the longhaired crossbred sheep meat

\begin{tabular}{|c|c|c|c|c|}
\hline \multirow[t]{2}{*}{ Fatty acid } & \multicolumn{2}{|c|}{ Loin } & \multicolumn{2}{|c|}{ Chump } \\
\hline & Mean & SD & Mean & SD \\
\hline Lauric Acid (C12:0) & 22.47 & 9.03 & 13.27 & 4.90 \\
\hline Myristic Acid (C14:0) & 212.82 & 136.26 & nd & - \\
\hline $\begin{array}{l}\text { Pentadecanoic Acid } \\
(\mathrm{C} 15: 0)\end{array}$ & 16.33 & 12.10 & nd & - \\
\hline Palmitic Acid (C16:0) & 1494.77 & 912.00 & nd & - \\
\hline $\begin{array}{l}\text { Heptadecanoic Acid } \\
\text { (C17:0) }\end{array}$ & 51.47 & 40.24 & 38.53 & 24.11 \\
\hline Stearic Acid (C18:0) & 933.86 & 774.81 & 635.65 & 427.18 \\
\hline $\begin{array}{l}\text { Myristoleic Acid } \\
(\mathrm{C} 14: 1)\end{array}$ & 9.97 & 2.63 & 6.18 & 0.65 \\
\hline $\begin{array}{l}\text { Palmitoleic Acid } \\
\text { (C16:1) }\end{array}$ & 143.58 & 79.47 & 99.32 & 29.15 \\
\hline $\begin{array}{l}\text { Elaidic Acid } \\
(\mathrm{C} 18: \ln 9 \mathrm{t})\end{array}$ & $11.80 *$ & - & 16.26 & 6.02 \\
\hline $\begin{array}{l}\text { Cis-11-Eicosenoic Acid } \\
\text { (C20:1) }\end{array}$ & 7.15 & 4.75 & $9.06^{*}$ & - \\
\hline $\begin{array}{l}\text { Linoleic Acid } \\
\text { (C18:2n6c) }\end{array}$ & 77.78 & 47.60 & 70.26 & 48.60 \\
\hline $\begin{array}{l}\text { Linolenic Acid } \\
\text { (C18:3n3) }\end{array}$ & 14.06 & 9.09 & 12.00 & 8.73 \\
\hline $\begin{array}{l}\text { Cis-11,14,17- } \\
\text { Eicosadienoic Acid } \\
\text { (C20:3n3) }\end{array}$ & 15.62 & 6.11 & 15.29 & 3.35 \\
\hline Total Fatty Acid & 2990.09 & 1995.64 & 865.65 & 545.61 \\
\hline
\end{tabular}

${ }^{*}$ found from one sample, $\mathrm{nd}=$ not found

The fatty acid profiles in loin and chump of longhaired and short-haired crossbred sheep meat were presented in Table 3 and 4. The number of fatty acid profiles in loin are greater than those in chump from both crossbreds. It was not found the Myristic acid (C14:0), the Pentadecanoic acid (C15:0), and the Palmitic acid (C16:0) in chump; nevertheless, those were found in loin. For the saturated fatty acid (SFA), the Palmitic acid (C16:0) was the most found in loin of both crossbred sheep (long-haired vs short-haired crossbred sheep; 1494.77 and $1138.60 \mathrm{mg} / 100 \mathrm{~g}$ ), the Steric acid (C17:0) was found in both loin and chump of long-haired crossbred (933.86 and $544.48 \mathrm{mg} / 100 \mathrm{~g}$ ); while, they were 635.65 and $544.48 \mathrm{mg} / 100 \mathrm{~g}$ in both loin and chump of short-haired crossbred. It had been known that fatty acid composition in ruminant has abundant of the saturation fatty acid as the result of biohydrogenation in rumen [2]. From the study of [4], the result showed that the Myristic acid (C14:0) and Palmitic acid (C16:0) are the two main fatty acids involved in increasing lowdensity lipoprotein (LDL), a risk factor for heart disease; therefore, reducing the C14:0 content in the muscle of sheep is an interesting and desiring. The presence of high levels of Palmitic Acid in different muscles was affected to the total fatty acid composition (TFA) in the muscles. Fatness level was related to the ratio of polyunsaturated fatty acid (PUFA) to saturated fatty acid (SFA), which is inversely correlated with intramuscular fat [2].

Table 4. Means and standard deviation values of the fatty acid profiles $(\mathrm{mg} / 100 \mathrm{~g})$ in the loin and chump muscle of shorthaired crossbred sheep meat

\begin{tabular}{|l|r|r|r|c|}
\hline \multirow{2}{*}{ Fatty acid } & \multicolumn{2}{|c|}{ Loin } & \multicolumn{2}{c|}{ Chump } \\
\cline { 2 - 5 } & Mean & \multicolumn{1}{c|}{ SD } & Mean & \multicolumn{1}{c|}{ SD } \\
\hline Lauric Acid (C12:0) & 21.17 & 7.82 & 11.42 & 5.14 \\
\hline Myristic Acid (C14:0) & 190.67 & 61.53 & nd & - \\
\hline $\begin{array}{l}\text { Pentadecanoic Acid } \\
\text { (C15:0) }\end{array}$ & 13.54 & 3.05 & nd & - \\
\hline Palmitic Acid (C16:0) & 1138.60 & 251.41 & nd & - \\
\hline $\begin{array}{l}\text { Heptadecanoic Acid } \\
\text { (C17:0) }\end{array}$ & 33.72 & 3.81 & 23.62 & 8.12 \\
\hline Stearic Acid (C18:0) & 544.48 & 79.93 & 338.43 & 90.57 \\
\hline $\begin{array}{l}\text { Myristoleic Acid } \\
\text { (C14:1) }\end{array}$ & 11.80 & 5.15 & 8.31 & 4.27 \\
\hline $\begin{array}{l}\text { Palmitoleic Acid } \\
\text { (C16:1) }\end{array}$ & 138.63 & 35.81 & 102.43 & 29.09 \\
\hline $\begin{array}{l}\text { Elaidic Acid } \\
\text { (C18:1n9t) }\end{array}$ & 16.72 & 3.28 & 10.38 & 3.63 \\
\hline $\begin{array}{l}\text { Cis-11-Eicosenoic } \\
\text { Acid (C20:1) }\end{array}$ & 3.37 & 0.20 & nd & - \\
\hline $\begin{array}{l}\text { Linoleic Acid } \\
\text { (C18:2n6c) }\end{array}$ & 75.92 & 13.04 & 70.81 & 11.23 \\
\hline $\begin{array}{l}\text { Linolenic Acid } \\
\text { (C18:3n3) }\end{array}$ & 15.02 & 0.38 & 13.34 & 3.33 \\
\hline $\begin{array}{l}\text { Cis-11,14,17- } \\
\text { Eicosadienoic Acid } \\
\text { (C20:3n3) }\end{array}$ & 17.80 & 1.37 & 18.64 & 1.95 \\
\hline $\begin{array}{l}\text { Total Fatty Acid } \\
\text { (TFA) }\end{array}$ & $\mathbf{2 2 1 0 . 7 2}$ & $\mathbf{4 4 6 . 0 5}$ & $\mathbf{5 6 4 . 3 3}$ & $\mathbf{1 5 2 . 9 9}$ \\
\hline
\end{tabular}

\subsection{The effects of crossbred groups and anatomical muscle positions on the chemical composition and fatty acid profiles in meat of short-haired and long-haired crossbred sheep}

Least squares means ( \pm standard error) of the chemical composition and fatty acid profiles effected by the shorthaired and long-haired crossbred sheep are presented in Table 5. There was no different $(\mathrm{P}>0.05)$ of the chemical composition, the saturated fatty acid (SFA), the monounsaturated fatty acid (MUFA), and the polyunsaturated fatty acid (PUFA) profiles between the crossbred groups. The experimental data indicate that the long-haired crossbred had the trend to accumulate the fat in muscle more than those the short-haired crossbred. Furthermore, the long-haired crossbred meat presented higher SFA, MUFA, and lower PUFA than those the short-haired crossbred. Fatty acid content has become very important as it implicates the health issue of human, 
the high ration of PUFA : SFA is required [4]. When the diet has the high unsaturated fatty acid (UFA), the use of ionophores may alter the meat lipid composition by affecting the ruminal dehydrogenation. In order to enhance the polyunsaturated fatty acid $\omega 3$ deposition in the muscle tissue, the higher forage levels in sheep diet is desired. It showed that Linoleic acid (C18:2n6c) are the essential fatty acid which cannot synthesize in sheep body. Therefore, it must be get from the diet of sheep [6].

Table 5. Least squares means ( \pm standard error) of the chemical composition and the fatty acid profiles (mg/100 g) effected by the long-haired and short-haired crossbred sheep muscle

\begin{tabular}{|l|c|c|}
\hline \multirow{2}{*}{ Traits } & \multicolumn{2}{c|}{ Crossbred sheep } \\
\cline { 2 - 3 } & Long hair & Short hair \\
\hline Moisture (\%) & $75.76 \pm 0.42$ & $75.59 \pm 0.42$ \\
\hline Dry matter (\%) & $24.24 \pm 0.42$ & $24.41 \pm 0.42$ \\
\hline Crude protein (\%) & $21.58 \pm 0.53$ & $21.46 \pm 0.50$ \\
\hline Crude fat (\%) & $9.07 \pm 0.58$ & $8.16 \pm 0.58$ \\
\hline Ash (\%) & $3.93 \pm 0.10$ & $3.96 \pm 0.10$ \\
\hline Saturated Fatty Acids (SFA) \\
\hline Lauric acid (C12:0) & $17.87 \pm 2.28$ & $16.30 \pm 2.14$ \\
\hline Margaric acid (C17:0) & $45.00 \pm 7.55$ & $28.67 \pm 7.55$ \\
\hline Stearic acid (C17:0) & $784.76 \pm 141.19$ & $441.45 \pm 141.19$ \\
\hline Monounsaturated Fatty Acids (MUFA) \\
\hline Myristoleic acid (C14:1) & $8.07 \pm 1.29$ & $10.05 \pm 1.23$ \\
\hline Palmitoic acid (C16:1) & $121.45 \pm 15.24$ & $120.53 \pm 15.24$ \\
\hline Elaidic acid (C18:1n9t) & $14.03 \pm 2.42$ & $13.55 \pm 1.40$ \\
\hline Polyunsaturated Fatty Acids (PUFA) & $73.36 \pm 11.76$ \\
\hline Linoleic acid (C18:2n6c) & $74.02 \pm 11.76$ & $14.18 \pm 2.04$ \\
\hline $\begin{array}{l}\text { Alpha-Linolenic acid } \\
\text { (C18:3n3) }\end{array}$ & $13.03 \pm 2.33$ & $18.22 \pm 1.43$ \\
\hline $\begin{array}{l}\text { cis-11,14,17-Eicosatrienoic } \\
\text { acid (C20:3n3) }\end{array}$ & $15.46 \pm 1.31$ & $\mathbf{1 3 8 7 . 5 3} \pm \mathbf{3 3 5 . 5 1}$ \\
\hline Total fatty acid & $\mathbf{1 9 2 7 . 8 7} \pm \mathbf{3 3 5 . 5 1}$ & \\
\hline
\end{tabular}

Table 6. Least squares means ( \pm standard error) of the chemical composition and the fatty acid profiles $(\mathrm{mg} / 100 \mathrm{~g})$ effected by the loin and chump muscle

\begin{tabular}{|c|c|c|}
\hline \multirow[t]{2}{*}{ Traits } & \multicolumn{2}{|c|}{ Muscle Type } \\
\hline & Loin & Chump \\
\hline Moisture (\%) & $75.55 \pm 0.42$ & $75.80 \pm 0.42$ \\
\hline Dry matter $(\%)$ & $24.45 \pm 0.42$ & $24.20 \pm 0.42$ \\
\hline Crude protein (\%) & $23.20 \pm 0.50^{\mathrm{a}}$ & $19.85 \pm 0.53^{\mathrm{b}}$ \\
\hline Crude fat (\%) & $8.20 \pm 0.58$ & $9.03 \pm 0.58$ \\
\hline Ash (\%) & $3.84 \pm 0.10$ & $4.04 \pm 0.10$ \\
\hline \multicolumn{3}{|l|}{ Saturated Fatty Acids (SFA) } \\
\hline Lauric acid (C12:0) & $21.82 \pm 2.28^{\mathrm{a}}$ & $12.34 \pm 2.15^{\mathrm{b}}$ \\
\hline Margaric acid $(\mathrm{C} 17: 0)$ & $42.60 \pm 7.55$ & $31.08 \pm 7.55$ \\
\hline Stearic acid (C17:0) & $739.17 \pm 141.19$ & $487.04 \pm 141.19$ \\
\hline \multicolumn{3}{|c|}{ Monounsaturated Fatty Acids (MUFA) } \\
\hline Myristoleic acid (C14:1) & $10.88 \pm 1.29$ & $7.24 \pm 1.23$ \\
\hline Palmitoic acid (C16:1) & $141.11 \pm 15.24$ & $100.87 \pm 15.24$ \\
\hline Elaidic acid (C18:1n9t) & $14.26 \pm 2.34$ & $13.32 \pm 1.53$ \\
\hline \multicolumn{3}{|c|}{ Polyunsaturated Fatty Acids (PUFA) } \\
\hline Linoleic acid (C18:2n6c) & $76.85 \pm 11.09$ & $70.53 \pm 12.39$ \\
\hline $\begin{array}{l}\text { Alpha-Linolenic acid } \\
\text { (C18:3n3) }\end{array}$ & $14.54 \pm 2.15$ & $12.67 \pm 2.22$ \\
\hline $\begin{array}{l}\text { cis-11,14,17-Eicosatrienoic } \\
\text { acid (C20:3n3) }\end{array}$ & $16.71 \pm 1.23$ & $16.97 \pm 1.49$ \\
\hline Total fatty acid & $2600.40 \pm 335.51^{\mathrm{a}}$ & $714.99 \pm 335.51^{b}$ \\
\hline
\end{tabular}

${ }^{\mathrm{ab}}$ Different letters within the same row differ significantly $(\mathrm{P}<0.01)$
Least squares means ( \pm standard error) of the chemical composition and fatty acid profiles effected by the lion and chump muscle are presented in Table 6. It had been shown that the parameter traits; the crude protein $(\mathrm{CP})$, the Lauric acid (C12:0), and the total fatty acid of the loins were highly significant greater than those chumps $(\mathrm{P}<0.1)$. The outcome of the plenty deposition of protein in the muscle was related to the number of muscle fiber, the muscle fiber type, and the protein type. The loin which is the sides between the lower ribs and pelvis has been realized as the high quality of muscle because it contains the plenty numbers of myofibrillar protein [3]. Nevertheless, the chump which is the muscle where the loin section meets the top of the hind legs is greater contraction than loin. This is the reason that chump has less myofibrillar protein and less fat deposit.

Lauric acid (C12:0), the 12-C saturated fatty acid (SFA) of intramuscular fat, is greater deposited in loin than in chump. It has been known that the chump has more muscle contraction than loin due to the enormous activity for moving at that muscle. This is the reason that the less muscle contract, the grater fat deposit. It has been shown that the interaction factor between the crossbred groups and the anatomical muscle position was unaffected all the traits studied $(\mathrm{P}>0.05)$.

\section{Conclusion}

The nutritional values (chemical composition and fatty acids profiles) were not affected by sheep crossbreds groups $(\mathrm{P}>0.05)$ in this study. Whereas, the anatomical muscle positions were the influence of some value traits; crude protein (CP), SFA (Lauric acid: C12:0), and total fatty acid (TFA). Interaction factor between the crossbred groups and the anatomical muscle positions was unaffected all the traits studied $(\mathrm{P}>0.05)$.

\section{References}

1 Department of Livestock Development. [online] http://www.dld.go.th/service/sheep/type.html (2018)

2 S. De Smet, K. Rase, and D. Demeyer, Animal Research, 53 (2004)

3 AOAC, Official methods of analysis (Association of official Chemist, Washington DC, 1992)

4 M.M.Y. Carneiro, R.H.de T.e B. de Goes, L.H.X. da Silva, A.R.M. Fernandes, R.T. de Oliveira, C.A.L. Cardoso, A.S.O. Hirata, Zootec 45, 6 (2016)

5 J.G.L. Regadas Filho, E.S. Pereira, P.G. Pimentel, A.B.S. Villarroel, A.N. Medeiros, Small Ruminant Research 109, 2-3 (2013)

6 T.P. Paim, A.F. Silva, R.F.S. Martins, B.O. Borges, P.M.T. Lima, C.C. Cardoso, G.I.F. Esteves, H. Louvandini and C. McManus, Small Ruminant Research 112, 1-3 (2013)

7 A.V. Fisher, M. Enser, R.I. Richardson, J.D. Wood, G.R. Nute, E. Kurt, L.A. Sinclair, R.G. Wilkinson, Meat Science 55 (2000) 


\section{Materials and Methods}

\subsection{Animals and production system}

The research was carried out at Suwanvajokkasikit Animal R\&D Institute, Kasetsart University, Kamphaeng Saen Campus, Nakorn Pathom Province, Thailand. The local altitude is $6 \mathrm{~m}$ above sea level at $13^{\circ} 59^{\prime} 2 \mathrm{~N}$ and $99^{\circ} 59^{\prime} 38^{\prime \prime} \mathrm{E}$. The temperature in the region varies between the minimum $18{ }^{\circ} \mathrm{C}$ to the maximum $40^{\circ} \mathrm{C}$, with an annual rainfall of 500-1,650 $\mathrm{mm}$. Ten male sheep, one-year-old with $25 \mathrm{~kg}$ initial body weight, equally represented the two crossbred groups; short-haired and long-haired crossbred sheep. Animals were raised in the confinement with the slatted floor. The animals were fed with $2 \mathrm{~kg} / \mathrm{d}$ TMR and free choice grass (Brachiaria mutica). The feed samples were analysed as the proximate analysis [3].

Table 1. Chemical composition of TMR and grass (Brachiaria mutica)

\begin{tabular}{|l|c|c|}
\hline \multirow{2}{*}{$\begin{array}{l}\text { Chemical } \\
\text { composition (\%) }\end{array}$} & TMR & Brachiaria mutica \\
\cline { 2 - 3 } & 88.83 & 21.97 \\
\hline Dry matter & 13.65 & 6.20 \\
\hline Crude Protein & 4.70 & 0.15 \\
\hline Crude Fat & 4.94 & 21.11 \\
\hline Crude Fiber & & \\
\hline
\end{tabular}

\subsection{Chemical composition and fatty acid profiles}

At slaughter, sheep were weighted, stunned and killed by exsanquination. The gastrointestinal tract and skin were removed. The carcasses were split into two identical longitudinal halves. Tested muscle samples from $M$. longissimus dorsi and M. semimembranosus were taken for laboratory analysis component as the following: the percentages of moisture and dry matterby oven drying $105{ }^{\circ} \mathrm{C}$, crude protein- by the Kjeldahl method, crude fat- by Soxhlet extractor and crude ash by $550{ }^{\circ} \mathrm{C}$ heat [3] and fatty acid profiles- by gas chromatography [4].

\subsection{Statistical analysis}

Descriptive statistics were performed to calculate mean values and standard deviations for all variables. In addition, least squares procedures were used to analyse data for the chemical composition and the fatty acid profiles. The General Linear Model (GLM) were used in the analyses of these characteristics included the fixed effects of crossbred groups and the muscle anatomical positions. The option PDIFF was used for calculating significant differences between least squares means.

$$
Y_{i j k}=\mu+B_{i}+M_{j}+e_{i j k}
$$

where:

$$
\text { Y the dependent variable }
$$

$\mu \quad$ the overall mean
$\mathrm{B}_{\mathrm{i}} \quad$ fixed crossbred group effect, ( $\mathrm{i}=$ short-haired, long-haired crossbred)

$\mathrm{M}_{\mathrm{j}} \quad$ fixed anatomical muscle position effect ( $\mathrm{j}=$ M. longissimus dorsi,

M. semimembranosus)

$e_{i j k}$ residual error

A pre-analysis showed that the interaction was not significant, so it was excluded out of the model.

\section{Results and discussions}

\subsection{The chemical composition in loin and chump of short-haired and long-haired crossbred sheep meat}

The chemical composition in loin and chump of shorthaired and long-haired crossbred sheep obtained in the experiment are described in Table 2. It was evidence that the percentage of moisture, crude protein, and crude fat of long-haired crossbred loin are greater than those short-haired crossbred loin $(75.83 \pm 1.19,23.37 \pm 1.77$, and $8.29 \pm 1.29$ vs $75.27 \pm 1.23,23.02 \pm 2.13$, and $8.11 \pm 1.10$, respectively). On the other hand, the percentage of dry matter and crude ash of short-haired crossbred loin are higher than those of long-haired crossbred loin $(24.73 \pm 1.23$ and $4.01 \pm 0.22$ vs $24.17 \pm 1.19$ and $3.68 \pm 0.36)$. It had been shown that the percentage of dry matter, crude fat and crude ash of long-haired crossbred chump are greater than those of short-haired crossbred chump. (24.31 $\pm 1.77,9.86 \pm 2.80$, and $4.17 \pm 0.36$ vs $24.09 \pm 0.94,8.20 \pm 1.66$, and $3.90 \pm 0.33$, respectively). Nonetheless, the percentage of moisture and crude protein of short-haired crossbred chump are higher than those of long-haired crossbred chump (75.91 \pm 0.94 , $19.91 \pm 1.09$ vs $75.69 \pm 1.77,19.80 \pm 0.84)$.

Table 2. Means ( \pm standard deviation), minimum and maximum values of the chemical composition in Loin and chump of the long-haired and short-haired crossbred sheep

\begin{tabular}{|l|c|c|c|c|c|c|}
\hline \multirow{2}{*}{$\begin{array}{l}\text { Chemical } \\
\text { composition }\end{array}$} & \multicolumn{2}{|c|}{ Long haired crossbred } & \multicolumn{3}{c|}{ Short haired crossbred } \\
\cline { 2 - 7 } & Mean \pm SD & Min & Max & Mean \pm SD & Min & Max \\
\hline Loin (M. longissimus dorsi) \\
\hline Moisture & $75.83 \pm 1.19$ & 73.89 & 76.91 & $75.27 \pm 1.23$ & 73.09 & 75.92 \\
\hline Dry matter & $24.17 \pm 1.19$ & 23.09 & 26.11 & $24.73 \pm 1.23$ & 24.08 & 26.91 \\
\hline $\begin{array}{l}\text { Crude } \\
\text { protein }\end{array}$ & $23.37 \pm 1.77$ & 20.65 & 25.04 & $23.02 \pm 2.13$ & 19.79 & 25.40 \\
\hline Crude fat & $8.29 \pm 1.29$ & 6.34 & 9.55 & $8.11 \pm 1.10$ & 6.84 & 9.54 \\
\hline Crude ash & $3.68 \pm 0.36$ & 3.30 & 4.08 & $4.01 \pm 0.22$ & 3.63 & 4.18 \\
\hline Chump (M. semimembranosus) & \multicolumn{5}{|l|}{} \\
\hline Moisture & $75.69 \pm 1.77$ & 74.26 & 78.54 & $75.91 \pm 0.94$ & 74.89 & 77.13 \\
\hline Dry matter & $24.31 \pm 1.77$ & 21.46 & 25.74 & $24.09 \pm 0.94$ & 22.87 & 25.11 \\
\hline $\begin{array}{l}\text { Crude } \\
\text { protein }\end{array}$ & $19.80 \pm 0.84$ & 19.04 & 20.71 & $19.91 \pm 1.09$ & 18.72 & 21.11 \\
\hline Crude fat & $9.86 \pm 2.80$ & 7.10 & 13.85 & $8.20 \pm 1.66$ & 6.55 & 10.04 \\
\hline Crude ash & $4.17 \pm 0.36$ & 3.91 & 4.80 & $3.90 \pm 0.33$ & 3.55 & 4.30 \\
\hline
\end{tabular}

The data from Table 2 have been shown that the percentage of crude fat of both mention muscles (loin and chump) of long-haired crossbred sheep were higher than those of short-haired crossbred sheep. The longhaired crossbred sheep which was expected to be the crossbred between the native and Dorper breed has the greater average body weight than those of the shorthaired crossbred sheep which was anticipated to be the 
crossbred between the native and Santa Inês breed (the live body weight at slaughter $35.26 \pm 3.24$ and $34.00 \pm 2.22$ $\mathrm{kg}$, respectively). There was the substantial increase in the energy and fat contents of the weight when the body weight was increased from $15-30 \mathrm{~kg}$ [5]. It had been known that fat depot in the muscle as the intramuscular fat is play the important role for the meat quality. The intramuscular fat was significantly associated with the sensory of meat such as the tenderness, juiciness, and flavour. Therefore, the Dorper breed has been suggested to be the terminal line of crossing breed for improving the great potential for growth and the ability for accumulate intramuscular fat in muscle. However, many previous studies showed that the Santa Inês breed, a naturalized hair breed, is known for its low-fat meat production and good maternal traits providing an opportunity for crossbred with specialized meat breeds [6], [7]. This breed was suggested to be the terminal line for producing the crossbred as well.

\subsection{The fatty acid profiles in loin and chump of short-haired and long-haired crossbred sheep meat}

Table 3. Means and standard deviation values of the fatty acid profiles $(\mathrm{mg} / 100 \mathrm{~g})$ in the loin and chump muscle of the longhaired crossbred sheep meat

\begin{tabular}{|l|r|r|r|r|}
\hline \multirow{2}{*}{ Fatty acid } & \multicolumn{2}{|c|}{ Loin } & \multicolumn{2}{c|}{ Chump } \\
\cline { 2 - 5 } & \multicolumn{1}{|c|}{ Mean } & \multicolumn{1}{c|}{ SD } & Mean & \multicolumn{1}{c|}{ SD } \\
\hline Lauric Acid (C12:0) & 22.47 & 9.03 & 13.27 & 4.90 \\
\hline Myristic Acid (C14:0) & 212.82 & 136.26 & nd & - \\
\hline $\begin{array}{l}\text { Pentadecanoic Acid } \\
\text { (C15:0) }\end{array}$ & 16.33 & 12.10 & nd & - \\
\hline Palmitic Acid (C16:0) & 1494.77 & 912.00 & nd & - \\
\hline $\begin{array}{l}\text { Heptadecanoic Acid } \\
\text { (C17:0) }\end{array}$ & 51.47 & 40.24 & 38.53 & 24.11 \\
\hline Stearic Acid (C18:0) & 933.86 & 774.81 & 635.65 & 427.18 \\
\hline $\begin{array}{l}\text { Myristoleic Acid } \\
\text { (C14:1) }\end{array}$ & 9.97 & 2.63 & 6.18 & 0.65 \\
\hline $\begin{array}{l}\text { Palmitoleic Acid } \\
\text { (C16:1) }\end{array}$ & 143.58 & 79.47 & 99.32 & 29.15 \\
\hline $\begin{array}{l}\text { Elaidic Acid } \\
\text { (C18:1n9t) }\end{array}$ & $11.80 *$ & - & 16.26 & 6.02 \\
\hline $\begin{array}{l}\text { Cis-11-Eicosenoic Acid } \\
\text { (C20:1) }\end{array}$ & 7.15 & 4.75 & $9.06 *$ & - \\
\hline $\begin{array}{l}\text { Linoleic Acid } \\
\text { (C18:2n6c) }\end{array}$ & 14.06 & 9.09 & 12.00 & 8.73 \\
\hline $\begin{array}{l}\text { Linolenic Acid } \\
\text { (C18:3n3) }\end{array}$ & $\mathbf{2 9 9 0 . 0 9}$ & $\mathbf{1 9 9 5 . 6 4}$ & $\mathbf{8 6 5 . 6 5}$ & $\mathbf{5 4 5 . 6 1}$ \\
\hline $\begin{array}{l}\text { Cis-11,14,17- } \\
\text { Eicosadienoic Acid } \\
\text { (C20:3n3) }\end{array}$ & 15.62 & 6.11 & 15.29 & 3.35 \\
\hline Total Fatty Acid & & & & 48.60 \\
\hline
\end{tabular}

* found from one sample, nd $=$ not found

The fatty acid profiles in loin and chump of longhaired and short-haired crossbred sheep meat were presented in Table 3 and 4 . The number of fatty acid profiles in loin are greater than those in chump from both crossbreds. It was not found the Myristic acid (C14:0), the Pentadecanoic acid (C15:0), and the Palmitic acid (C16:0) in chump; nevertheless, those were found in loin. For the saturated fatty acid (SFA), the Palmitic acid (C16:0) was the most found in loin of both crossbred sheep (long-haired vs short-haired crossbred sheep; 1494.77 and $1138.60 \mathrm{mg} / 100 \mathrm{~g}$ ), the Steric acid (C17:0) was found in both loin and chump of long-haired crossbred (933.86 and $544.48 \mathrm{mg} / 100 \mathrm{~g}$ ); while, they were 635.65 and $544.48 \mathrm{mg} / 100 \mathrm{~g}$ in both loin and chump of short-haired crossbred. It had been known that fatty acid composition in ruminant has abundant of the saturation fatty acid as the result of biohydrogenation in rumen [2]. From the study of [4], the result showed that the Myristic acid (C14:0) and Palmitic acid (C16:0) are the two main fatty acids involved in increasing lowdensity lipoprotein (LDL), a risk factor for heart disease; therefore, reducing the $\mathrm{C} 14: 0$ content in the muscle of sheep is an interesting and desiring. The presence of high levels of Palmitic Acid in different muscles was affected to the total fatty acid composition (TFA) in the muscles. Fatness level was related to the ratio of polyunsaturated fatty acid (PUFA) to saturated fatty acid (SFA), which is inversely correlated with intramuscular fat [2].

Table 4. Means and standard deviation values of the fatty acid profiles $(\mathrm{mg} / 100 \mathrm{~g})$ in the loin and chump muscle of shorthaired crossbred sheep meat

\begin{tabular}{|l|r|r|r|r|}
\hline \multirow{2}{*}{ Fatty acid } & \multicolumn{2}{|c|}{ Loin } & \multicolumn{2}{c|}{ Chump } \\
\cline { 2 - 5 } & \multicolumn{1}{|c|}{ Mean } & \multicolumn{1}{|c|}{ SD } & \multicolumn{1}{c|}{ Mean } & \multicolumn{1}{c|}{ SD } \\
\hline Lauric Acid (C12:0) & 21.17 & 7.82 & 11.42 & 5.14 \\
\hline Myristic Acid (C14:0) & 190.67 & 61.53 & nd & - \\
\hline $\begin{array}{l}\text { Pentadecanoic Acid } \\
\text { (C15:0) }\end{array}$ & 13.54 & 3.05 & nd & - \\
\hline Palmitic Acid (C16:0) & 1138.60 & 251.41 & nd & - \\
\hline $\begin{array}{l}\text { Heptadecanoic Acid } \\
\text { (C17:0) }\end{array}$ & 33.72 & 3.81 & 23.62 & 8.12 \\
\hline Stearic Acid (C18:0) & 544.48 & 79.93 & 338.43 & 90.57 \\
\hline $\begin{array}{l}\text { Myristoleic Acid } \\
\text { (14:1) }\end{array}$ & 11.80 & 5.15 & 8.31 & 4.27 \\
\hline $\begin{array}{l}\text { Palmitoleic Acid } \\
\text { (C16:1) }\end{array}$ & 138.63 & 35.81 & 102.43 & 29.09 \\
\hline $\begin{array}{l}\text { Elaidic Acid } \\
\text { C18:1n9t) }\end{array}$ & 16.72 & 3.28 & 10.38 & 3.63 \\
\hline $\begin{array}{l}\text { Cis-11-Eicosenoic } \\
\text { Acid (C20:1) }\end{array}$ & 3.37 & 0.20 & nd & - \\
\hline $\begin{array}{l}\text { Linoleic Acid } \\
\text { (C18:2n6c) }\end{array}$ & 75.92 & 13.04 & 70.81 & 11.23 \\
\hline $\begin{array}{l}\text { Linolenic Acid } \\
\text { (C18:3n3) }\end{array}$ & 15.02 & 0.38 & 13.34 & 3.33 \\
\hline $\begin{array}{l}\text { Cis-11,14,17- } \\
\text { Eicosadienoic Acid } \\
\text { C20:3n3) }\end{array}$ & 17.80 & 1.37 & 18.64 & 1.95 \\
\hline $\begin{array}{l}\text { Total Fatty Acid } \\
\text { (TFA) }\end{array}$ & $\mathbf{2 2 1 0 . 7 2}$ & $\mathbf{4 4 6 . 0 5}$ & $\mathbf{5 6 4 . 3 3}$ & $\mathbf{1 5 2 . 9 9}$ \\
\hline
\end{tabular}

\subsection{The effects of crossbred groups and anatomical muscle positions on the chemical composition and fatty acid profiles in meat of short-haired and long-haired crossbred sheep}

Least squares means ( \pm standard error) of the chemical composition and fatty acid profiles effected by the shorthaired and long-haired crossbred sheep are presented in Table 5. There was no different $(\mathrm{P}>0.05)$ of the chemical composition, the saturated fatty acid (SFA), the monounsaturated fatty acid (MUFA), and the polyunsaturated fatty acid (PUFA) profiles between the crossbred groups. The experimental data indicate that the long-haired crossbred had the trend to accumulate the fat in muscle more than those the short-haired crossbred. Furthermore, the long-haired crossbred meat presented higher SFA, MUFA, and lower PUFA than those the short-haired crossbred. Fatty acid content has become very important as it implicates the health issue of human, 
the high ration of PUFA : SFA is required [4]. When the diet has the high unsaturated fatty acid (UFA), the use of ionophores may alter the meat lipid composition by affecting the ruminal dehydrogenation. In order to enhance the polyunsaturated fatty acid $\omega 3$ deposition in the muscle tissue, the higher forage levels in sheep diet is desired. It showed that Linoleic acid $(\mathrm{C} 18: 2 \mathrm{n} 6 \mathrm{c})$ are the essential fatty acid which cannot synthesize in sheep body. Therefore, it must be get from the diet of sheep [6].

Table 5. Least squares means ( \pm standard error) of the chemical composition and the fatty acid profiles $(\mathrm{mg} / 100 \mathrm{~g})$ effected by the long-haired and short-haired crossbred sheep muscle

\begin{tabular}{|l|c|c|}
\hline \multirow{2}{*}{ Traits } & \multicolumn{2}{c|}{ Crossbred sheep } \\
\cline { 2 - 3 } & Long hair & Short hair \\
\hline Moisture (\%) & $75.76 \pm 0.42$ & $75.59 \pm 0.42$ \\
\hline Dry matter (\%) & $24.24 \pm 0.42$ & $24.41 \pm 0.42$ \\
\hline Crude protein (\%) & $21.58 \pm 0.53$ & $21.46 \pm 0.50$ \\
\hline Crude fat (\%) & $9.07 \pm 0.58$ & $8.16 \pm 0.58$ \\
\hline Ash (\%) & $3.93 \pm 0.10$ & $3.96 \pm 0.10$ \\
\hline Saturated Fatty Acids (SFA) \\
\hline Lauric acid (C12:0) & $17.87 \pm 2.28$ & $16.30 \pm 2.14$ \\
\hline Margaric acid (C17:0) & $45.00 \pm 7.55$ & $28.67 \pm 7.55$ \\
\hline Stearic acid (C17:0) & $784.76 \pm 141.19$ & $441.45 \pm 141.19$ \\
\hline Monounsaturated Fatty Acids (MUFA) \\
\hline Myristoleic acid (C14:1) & $8.07 \pm 1.29$ & $10.05 \pm 1.23$ \\
\hline Palmitoic acid (C16:1) & $121.45 \pm 15.24$ & $120.53 \pm 15.24$ \\
\hline Elaidic acid (C18:1n9t) & $14.03 \pm 2.42$ & $13.55 \pm 1.40$ \\
\hline Polyunsaturated Fatty Acids (PUFA) \\
\hline Linoleic acid (C18:2n6c) & $74.02 \pm 11.76$ & $73.36 \pm 11.76$ \\
\hline $\begin{array}{l}\text { Alpha-Linolenic acid } \\
\text { (C18:3n3) }\end{array}$ & $13.03 \pm 2.33$ & $14.18 \pm 2.04$ \\
\hline $\begin{array}{l}\text { cis-11,14,17-Eicosatrienoic } \\
\text { acid (C20:3n3) }\end{array}$ & $15.46 \pm 1.31$ & $18.22 \pm 1.43$ \\
\hline Total fatty acid & $\mathbf{1 9 2 7 . 8 7} \pm \mathbf{3 3 5 . 5 1}$ & $\mathbf{1 3 8 7 . 5 3} \pm \mathbf{3 3 5 . 5 1}$ \\
\hline
\end{tabular}

Table 6. Least squares means ( \pm standard error) of the chemical composition and the fatty acid profiles $(\mathrm{mg} / 100 \mathrm{~g})$ effected by the loin and chump muscle

\begin{tabular}{|l|c|c|}
\hline \multirow{2}{*}{ Traits } & \multicolumn{2}{|c|}{ Muscle Type } \\
\cline { 2 - 3 } & Loin & Chump \\
\hline Moisture (\%) & $75.55 \pm 0.42$ & $75.80 \pm 0.42$ \\
\hline Dry matter (\%) & $24.45 \pm 0.42$ & $24.20 \pm 0.42$ \\
\hline Crude protein (\%) & $23.20 \pm 0.50^{\mathrm{a}}$ & $19.85 \pm 0.53^{\mathrm{b}}$ \\
\hline Crude fat (\%) & $8.20 \pm 0.58$ & $9.03 \pm 0.58$ \\
\hline Ash (\%) & $3.84 \pm 0.10$ & $4.04 \pm 0.10$ \\
\hline Saturated Fatty Acids (SFA) \\
\hline Lauric acid (C12:0) & $21.82 \pm 2.28^{\mathrm{a}}$ & $12.34 \pm 2.15^{\mathrm{b}}$ \\
\hline Margaric acid (C17:0) & $42.60 \pm 7.55$ & $31.08 \pm 7.55$ \\
\hline Stearic acid (C17:0) & $739.17 \pm 141.19$ & $487.04 \pm 141.19$ \\
\hline Monounsaturated Fatty Acids (MUFA) \\
\hline Myristoleic acid (C14:1) & $10.88 \pm 1.29$ & $7.24 \pm 1.23$ \\
\hline Palmitoic acid (C16:1) & $141.11 \pm 15.24$ & $100.87 \pm 15.24$ \\
\hline Elaidic acid (C18:1n9t) & $14.26 \pm 2.34$ & $13.32 \pm 1.53$ \\
\hline Polyunsaturated Fatty Acids (PUFA) & $70.53 \pm 12.39$ \\
\hline Linoleic acid (C18:2n6c) & $76.85 \pm 11.09$ & $12.67 \pm 2.22$ \\
\hline $\begin{array}{l}\text { Alpha-Linolenic acid } \\
\text { (C18:3n3) }\end{array}$ & $14.54 \pm 2.15$ & $16.97 \pm 1.49$ \\
\hline $\begin{array}{l}\text { cis-11,14,17-Eicosatrienoic } \\
\text { acid (C20:3n3) }\end{array}$ & $16.71 \pm 1.23$ & $\mathbf{7 1 4 . 9 9} \pm \mathbf{3 3 5 . 5 1}{ }^{\mathbf{b}}$ \\
\hline Total fatty acid & $\mathbf{2 6 0 0 . 4 0 \pm 3 3 5 . 5 1}$ & $\mathbf{7 1 4}$
\end{tabular}

${ }^{\mathrm{ab}}$ Different letters within the same row differ significantly $(\mathrm{P}<0.01)$
Least squares means ( \pm standard error) of the chemical composition and fatty acid profiles effected by the lion and chump muscle are presented in Table 6 . It had been shown that the parameter traits; the crude protein $(\mathrm{CP})$, the Lauric acid $(\mathrm{C} 12: 0)$, and the total fatty acid of the loins were highly significant greater than those chumps $(\mathrm{P}<0.1)$. The outcome of the plenty deposition of protein in the muscle was related to the number of muscle fiber, the muscle fiber type, and the protein type. The loin which is the sides between the lower ribs and pelvis has been realized as the high quality of muscle because it contains the plenty numbers of myofibrillar protein [3]. Nevertheless, the chump which is the muscle where the loin section meets the top of the hind legs is greater contraction than loin. This is the reason that chump has less myofibrillar protein and less fat deposit.

Lauric acid (C12:0), the 12-C saturated fatty acid (SFA) of intramuscular fat, is greater deposited in loin than in chump. It has been known that the chump has more muscle contraction than loin due to the enormous activity for moving at that muscle. This is the reason that the less muscle contract, the grater fat deposit. It has been shown that the interaction factor between the crossbred groups and the anatomical muscle position was unaffected all the traits studied $(\mathrm{P}>0.05)$.

\section{Conclusion}

The nutritional values (chemical composition and fatty acids profiles) were not affected by sheep crossbreds groups $(\mathrm{P}>0.05)$ in this study. Whereas, the anatomical muscle positions were the influence of some value traits; crude protein (CP), SFA (Lauric acid: C12:0), and total fatty acid (TFA). Interaction factor between the crossbred groups and the anatomical muscle positions was unaffected all the traits studied $(\mathrm{P}>0.05)$.

\section{References}

1 Department of Livestock Development. [online] http://www.dld.go.th/service/sheep/type.html (2018)

2 S. De Smet, K. Rase, and D. Demeyer, Animal Research, 53 (2004)

3 AOAC, Official methods of analysis (Association of official Chemist, Washington DC, 1992)

4 M.M.Y. Carneiro, R.H.de T.e B. de Goes, L.H.X. da Silva, A.R.M. Fernandes, R.T. de Oliveira, C.A.L. Cardoso, A.S.O. Hirata, Zootec 45, 6 (2016)

5 J.G.L. Regadas Filho, E.S. Pereira, P.G. Pimentel, A.B.S. Villarroel, A.N. Medeiros, Small Ruminant Research 109, 2-3 (2013)

6 T.P. Paim, A.F. Silva, R.F.S. Martins, B.O. Borges, P.M.T. Lima, C.C. Cardoso, G.I.F. Esteves, H. Louvandini and C. McManus, Small Ruminant Research 112, 1-3 (2013)

7 A.V. Fisher, M. Enser, R.I. Richardson, J.D. Wood, G.R. Nute, E. Kurt, L.A. Sinclair, R.G. Wilkinson, Meat Science 55 (2000) 